Jurnal Hukum Mimbar Justitia

Fakultas Hukum Universitas Suryakancana

Vol. 3 No. 2 - Desember 2017 p. 157-176

ISSN: 2477-5681 (Cetak), ISSN: 2580-0906 (Online)

Open Access at: https://jurnal.unsur.ac.id/jmj

\title{
PELUANG DAN ANCAMAN MASYARAKAT EKONOMI ASEAN (MEA) BAGI PERKEMBANGAN HAK KEKAYAAN INTELEKTUAL INDONESIA
}

\author{
Hilman Nur \\ Fakultas Hukum Universitas Suryakancana \\ E-mail: hilmannur80@gmail.com
}

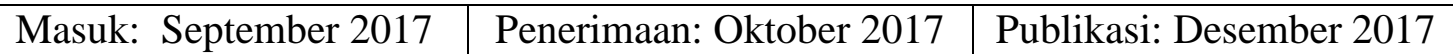

\begin{abstract}
ABSTRAK
Komunitas Masyarakat Ekonomi ASEAN (MEA) sudah tidak dapat ditolak lagi, karena saat ini pelaksanaannya sudah berjalan sejak tahun 2015 yang lalu. MEA merupakan bentuk integrasi ekonomi ASEAN, dalam hal ini semua negara-negara yang berada di kawasan Asia Tenggara sudah sepakat menerapkan sistem perdagangan bebas dengan tujuan menjadikan kawasan ASEAN menjadi kawasan yang lebih stabil, makmur dan kompetitif dalam pembangunan ekonomi.

Karakteristik MEA yang berbasis pada pasar tunggal dan produksi, ekonomi yang kompetitif, pembangunan ekonomi yang adil, dan kawasan yang terintegrasi dalam hal ekonomi global sudah seharusnya membawa negara-negara yang berada di kawasan Asia Tenggara khususnya Indonesia mampu meningkatkan kesejahteraan ekonomi bagi warga negaranya, bukan sebaliknya malah menjadi ancaman bagi perekonomian Indonesia khususnya dalam bidang Hak Kekayaan Intelektual dimana pasca ratifikasi kesepakatan WTO/TRIPs Hak Kekayaan Intelektual ini sangat erat sekali dengan dunia perdagangan/bisnis (ekonomi).

Indonesia yang sangat kaya akan sumber daya alam dan sumber daya manusia sebagai faktor produksi yang sangat penting dalam pembangunan, perlu diarahkan dan dikembangkan ke arah yang positif khususnya dalam bidang hak kekayaan intelektual, karena ke depan persaingan dengan bangsa lain tidak cukup hanya mengandalkan kekayaan sumber daya alam saja, mengingat sumber daya alam tersebut akan dan pasti habis. Oleh karena itu Indonesia sudah seharusnya merespon pelaksanaan MEA ini secara positif dan dijadikan peluang yang bagus dalam upaya meningkatkan kesejahteraan masyarakat dengan menerapkan sistem hak kekayaan intelektual sebagaimana yang telah dilakukan oleh negara-negara maju seperti Amerika, Jepang dan lain-lain.
\end{abstract}

Kata kunci : Masyarakat Ekonomi Asean (MEA), Cita Negara Hukum Berkesejahteraan, Sistem Hukum Hak Kekayaan Intelektual Indonesia.

ABSTRACT

The ASEAN Economic Community (MEA) can not be denied again, because the current implementation has been running since the year 2015. MEA is a form of economic integration of ASEAN, in which case all the countries located in the South-East Asia 
have already agreed to implement the free trade system with the goal of making ASEAN into a more stable, prosperous and competitive in economic development.

Characteristics of the MEA, based on a single market and production, a competitive economy, a fair economic development, and an integrated area in terms of the global economy was supposed to bring the countries located in the South-East Asia Indonesia in particular was able to increase economic prosperity for its citizens, not vice versa and even be a threat to Indonesia's economy especially in the field of intellectual property rights where the post ratification agreement of the WTO/TRIPs Right Intellectual property is very closely with the world trade/business (Economics).

Indonesia which is very rich in natural resources and human resources as production factors are very important in development, need to be directed and developed in a positive direction, especially in the field of intellectual property, due to the front competition with other Nations is not enough just to rely on the wealth of natural resources, given the natural resources and definitely exhausted. Therefore Indonesia was supposed to respond to the implementation of the MEA is positively and made a great opportunity in an attempt to improve the welfare of society by applying the system of intellectual property rights, as has been done by developed countries such as America, Japan and others.

Keywords: $\quad$ The Asean economic community (MEA), the State of mind of the law Berkesejahteraan, the legal system of intellectual property rights of Indonesia.

\section{PENDAHULUAN.}

Komunitas Masyarakat Ekonomi ASEAN (MEA) memang bukan merupakan isu baru diantara negaranegara ASEAN khususnya Indonesia. Isu komunitas MEA ini sudah muncul sejak pertama kali Organisasi ASEAN tersebut didirikan tahun 1967 di Bangkok Thailand. ASEAN (Association of Southeast Asian Nationts) pada mulanya didirikan oleh lima negara di Asia Tenggara, yakni Indonesia, Malaysia, Thailand, Phillipina dan Singapura.

Pada awalnya pembentukan perhimpunan ASEAN sebenarnya dilatarbelakangi oleh kekhawatiran negara-negara Asia Tenggara terhadap ancaman eksternal dan internal di kawasan tersebut. Ancaman eksternal adalah semakin kuatnya pengaruh komunisme di kawasan Asia umumnya. Selain itu perang Vietnam pada waktu itu semakin panas. Sementara ancaman internal adalah adanya pertikaian sesama negara di kawasan ini, misalnya konfrontasi antara Malaysia dan Indonesia. $^{1}$

Deklarasi Bangkok merupakan instrumen terpenting bagi ASEAN.

1 Huala Adolf, Hukum Ekonomi Internasional, CV Keni Media, Bandung, Cet. Kelima, 2010, hlm. 97. 
Preamble Deklarasi menegaskan keinginan negara-negara anggota untuk mendirikan suatu fondasi yang kokoh untuk tindakan bersama guna memajukan kerjasama regional, memperkuat stabilitas ekonomi dan sosial, serta untuk memelihara keamanan dari campur tangan pihak luar.

Tujuan dan maksud ASEAN sendiri adalah untuk meningkatkan pertumbuhan ekonomi, memajukan pembangunan sosial dan budaya, memajukan perdamaian dan stabilitas regional, memajukan kerjasama aktif dan saling bantu membantu di bidang ekonomi, sosial, budaya, teknik, ilmu pengetahuan dan administrasi; pemberian bantuan di bidang pelatihan dan penelitian di bidang pendidikan, profesional, teknik; kerjasama di bidang pertanian, industri, perdagangan (termasuk studi mengenai perdagangan komoditi internasional), transportasi, komunikasi, dan standar hidup; memajukan kajian mengenai Asia Tenggara; dan memajukan kerjasama dengan organisasi internasional dan regional lainnya yang memiliki maksud dan tujuan yang sama dengan ASEAN. ${ }^{2}$
Tahun-tahun

pertama pembentukannya, ASEAN tidak begitu aktif. Tidak banyak kebijakan atau pengaturan bersama yang berhasil dikeluarkan. ASEAN baru kelihatan kegiatannya pada bulan Februari tahun 1976 ketika pertemuan tingkat tinggi para penguasa ASEAN berlangsung di Bali. Pertemuan Bali ini menghasilkan 3 (tiga) kesepakatan penting, yakni :

1. The Agreement of Establishment of the Permanent Secretariat of ASEAN;

2. The Declaration of ASEAN Concord; dan

3. The Treaty of Amity and Cooperation in South-East Asia. ${ }^{3}$

Setelah lebih dari 40 (empat puluh) tahun berdiri, akhirnya ASEAN memiliki landasan hukum kuat. Bulan November 2007, kesepuluh negara ASEAN secara aklamasi menyetujui dan mengesahkan Piagam ASEAN (the ASEAN Charter). Berdasarkan Piagam tersebut, untuk berlakunya Piagam harus diratifikasi oleh seluruh anggotanya. Singapura adalah negara pertama yang meratifikasinya pada awal Januari 2008, disusul negara ASEAN lainnya.

Ibid, hlm. 98.

$3 \quad$ Ibid, hlm. 97-98. 
Piagam ASEAN sebenarnya memuat dan menegaskan kembali praktik dan kelembagaan hukum yang telah lama dilakukannya. Misalnya ASEAN mempertahankan kebijakan pengambilan suara berdasarkan musyawarah untuk mufakat atau konsultasi dan konsensus. Hal lainnya yang penting yang termuat dalam Piagam tersebut juga antara lain; Pertama, adanya pengaturan Badan Hak Asasi Manusia (HAM) ASEAN. Tujuan utama pembentukan badan ini adalah untuk memperkuat demokrasi, good governance, rule of law, dan memajukan perlindungan HAM dan kebebasan fundamental. Kedua, Integritas ekonomi. Ketiga, memberikan kewenangan yang lebih besar kepada Sekertariat ASEAN di Jakarta. Keempat, menetapkan bahasa resmi ASEAN adalah bahasa Inggris. Untuk maksud itu, maka Piagam ASEAN mempercepat target pencapaiannya dari semula tahun 2020 menjadi 2015. Percepatan ini dipandang perlu untuk menangkal pertumbuhan kekuatan regional di kawasan Asia yaitu Cina dan India. $^{4}$
Saat ini, pelaksanaan Masyarakat Ekonomi ASEAN (MEA) sudah bergulir. Semula pelaksanaannya akan dimulai pada 1 Januari 2015, namun tenggat waktu tersebut diundur menjadi 31 Desember 2015 karena dianggap masih banyak kurangnya persiapan untuk sebuah kawasan yang terintegrasi.

Masyarakat Ekonomi ASEAN (MEA) merupakan bentuk integrasi ekonomi ASEAN, artinya semua negara-negara yang berada di kawasan Asia Tenggara (10 negara) termasuk Indonesia di dalamnya menerapkan sistem perdagangan bebas dengan tujuan menjadikan kawasan ASEAN menjadi kawasan yang lebih stabil, makmur dan kompetitif dalam pembangunan ekonomi. Karakteristik MEA sendiri meliputi : (1) berbasis pada pasar tunggal dan produksi, (2) kawasan ekonomi yang sangat kompetitif, (3) wilayah pembangunan ekonomi yang adil, dan (4) kawasan yang begitu terintegrasi dalam hal ekonomi global.

Pembentukan MEA ini pula tentunya diharapkan banyak memberikan manfaat positif khususnya bagi negara-negara anggotanya, diantara harapan tersebut adalah :

$4 \quad$ Ibid, hlm. 102-103. 
1. MEA akan mendorong arus investasi dari luar masuk ke dalam negeri yang akan menciptakan multiplier effect dalam berbagai sektor khususnya dalam bidang pembangunan ekonomi.

2. Kondisi pasar yang satu (pasar tunggal) membuat kemudahan dalam hal pembentukan joint venture (kerjasama) antara perusahaan-perusahaan di wilayah ASEA, sehinggaakses terhadap bahan produksi semakin mudah.

3. Pasar Asia Tenggara merupakan pasar besar yang begitu potensial dan juga menjanjikan dengan luas wilayah sekitar 4,5 juta kilometer persegi dan jumlah penduduk yang mencapai 600 juta jiwa.

4. MEA memberikan peluang kepada negara-negara anggota ASEAN dalam hal meningkatkan kecepatan perpindahan sumber daya manusia dan modal yang merupakan dua faktor produksi yang sangat penting.

5. Khusus untuk bidang teknologi, diberlakukannya MEA ini menciptakan adanya transfer teknologi dari negara-negara maju ke negara-negara berkembang yang ada di wilayah Asia Tenggara.

Selanjutnya dengan telah digulirkannya pelaksanaan MEA ini, maka timbul pertanyaan sekaligus kekhawatiran, apakah MEA ini merupakan peluang atau justru malah ancaman bagi perkembangan industri lokal di Indonesia, mengingat dengan sistem MEA ini arus barang dari negara-negara ASEAN akan mudah dilakukan tanpa hambatan yang berarti, sementara sistem Hak Kekayaan Intelektual Indonesia masih dalam pencarian bentuk dan format yang tepat dalam pelaksanaannya.

\section{METODE PENELITIAN}

Metodologi merupakan unsur mutlak yang harus ada dalam kegiatan penelitian, untuk itu dalam suatu penelitian, peneliti perlu menggunakan metode yang tepat, sehingga hasil penelitiannya dapat bernilai ilmiah. ${ }^{5}$

\section{Metode Pendekatan.}

Metode yang digunakan dalam penelitian ini menggunakan pendekatan yuridis normatif, yaitu penelitian yang 
dilakukan dengan mendasarkan pada data kepustakaan atau data sekunder. ${ }^{6}$

\section{Spesifiksi Penelitian.}

Spesifikasi penelitian penulisan hukum ini adalah deskriptif analisis. Dengan pendekatan deskriptif, diharapkan penelitian ini dapat memberikan gambaran umum, menyeluruh dan sistematis tentang peluang dan ancaman komunitas Masyarakat Ekonomi Asean (MEA) terhadap perkembangan Hak Kekayaan Intelektual Indonesia.

\section{Menurut Hadari Nawawie,} metode penelitian deskriptif ini mempunyai ciri pokok, yakni :

1. Memusatkan perhatian pada masalah-masalah yang ada pada setiap penelitian yang dilakukan (saat sekarang) atau masalahmasalah yang bersifat aktual;

2. Menggambarkan fakta-fakta tentang masalah yang diselidiki sebagaimana adanya diiringi dengan interpretasi rasional. ${ }^{7}$

Sedangkan pendekatan analisis dilaksanakan untuk memberikan suatu

6 Soerjono Soekanto, Pengantar Penelitian Hukum, Jakarta, UI Press, 1986, hlm.10.

7 H. Hadari Nawawie, Metode Penelitian Bidang Sosial, Gadjah Mada University Press, Yogyakarta, 1983, hlm. 63. hasil analisa atas data-data yang telah didapatkan dari lapangan baik dari sumber hukum primer maupun sumber hukum sekunder dan data primer serta data sekunder.

\section{Tahap Penelitian}

Studi Kepustakaan

(Library

Research). Pengumpulan data-data dengan cara mempelajari peraturan perundang-undangan dan literaturliteratur ilmiah lain yang erat hubungannya dengan masalah yang dibahas dalam penulisan hukum ini.

\section{Pengolahan Data :}

Untuk menarik kesimpulan dari hasil penelitian, maka semua data yang terkumpul dianalisis dengan menggunakan deskriptif analisis, yaitu menggambarkan suatu kejadian atau masalah berdasarkan data sekunder berupa bahan-bahan hukum primer.

\section{PEMBAHASAN.}

Negara Indonesia adalah negara hukum sebagaimana yang dijelaskan dalam Konstitusi Undang-Undang Dasar (UUD) 1945, menyatakan bahwa negara Indonesia adalah negara yang berdasar atas hukum (rechtsstaat), tidak 
berdasarkan kekuasaan belaka (machtsstaat).

Dalam

perkembangan

selanjutnya, Indonesia sendiri menganut konsep negara hukum yang dikembangkan ke arah tujuannya yaitu negara hukum berkesejahteraan.

Sebagaimana yang disebutkan dalam Pembukaan Undang-Undang Dasar 1945 yakni:

1. Melindungi segenap bangsa Indonesia dan seluruh tumpah darah Indonesia.

2. Untuk memajukan kesejahteraan umum.

3. Mencerdaskan kehidupan bangsa.

4. Melaksanakan ketertiban dunia yang berdasarkan kemerdekaan, perdamaian abadi dan keadilan sosial.

Konsep negara kesejahteraan pada dasarnya dikembangkan dalam konteks ekonomi pasar (market economy) dan dalam hubungannya dengan sistem ekonomi campuran (mixed economy). Peranan negara dalam konsep negara kesejahteraan menurut Briggs adalah "...to modify the play of market forces" (...memodifikasikan berbagai kekuatan pasar). ${ }^{8}$ Perlunya pengendalian dan

8 A. Briggs, The Welfare State in Historical Perspective, dalam; Archives Europeennes pembatasan terhadap bekerjanya kekuatan-kekuatan pasar tersebut adalah untuk mengatasi unsur-unsur negatif yag tidak diharapkan sebagai hasil (outcome) atau akibat bekerjanya kekuatan-kekuatan pasar tersebut. Menurut Goddin dalam negara kesejahteraan, campur tangan negara dalam mengatur pasar dilukiskannya sebagai “... a public intervention in private market economy" (...campur tangan publik dalam ekonomi pasar swasta). ${ }^{9}$ Tujuannya tidak lain adalah guna meningkatkan kesejahteraan umum (promoting public welfare) dan memaksimumkan kesejahteraan sosial (to maximize social welfare), sehingga memperkecil dampak kegagalan pasar (market pailure) terhadap masyarakat yang disebabkan oleh apa yang disebutnya moral hazard dan penggunaan yang keliru terhadap

de Sociologie 2: 221-58 sebagaimana dikutip dari Donald J. Moon (editor) Responsibility Rights \& Welfare, The Teory of the Welfare State, Westview Press Inc., Boulder, Colorado, 1988, hlm. 21, dalam Johnny brahim, Hukum Persaingan Usaha, Bayumedia Publishing, Malang, Cet. 2, 2007, hlm. 32.

9 Robert E. Goddin, Reason for Welfare, Economic, Sociological and Political but Ultimately Moral, dalam: Responsibility Right \& Welfare, The Theory of the Welfare State, Donald J. Moon (editor), ibid, hlm. 22, dalam Johnny brahim, Hukum Persaingan Usaha, Bayumedia Publishing, Malang, Cet. 2, 2007, hlm. 32-33. 
berbagai sumber daya (missalocation of resources). ${ }^{10}$ Dalam hal ini, apa yang dikemukakan oleh Oscar Lafontaine menjadi penting. "Krisis di Asia Timur seperti yang pernah terjadi di Meksiko sebelumnya menunjukkan bahwa pasar tidak dapat menyelesaikan segalanya. Sebaliknya, pasar yang tidak dikontrol menyebabkan perkembangan negatif, sehingga semua orang di dunia harus membayarnya dengan kehilangan yang sangat besar, termasuk kehilangan mata pencahariannya". ${ }^{11}$

Konsep negara kesejahteraan bermula dari gagasan yang muncul dalam Beveridge Report, yaitu berisi laporan dari Beveridge, seorang anggota parlemen Inggris yang mengusulkan keterlibatan negara di bidang ekonomi dalam hal yang berhubungan dengan pemerataan pendapatan masyarakat, kesejahteraan sosial sejak manusia lahir sampai mati (from the cradle to the grave), lapangan kerja, pengawasan atas

10 Robert E. Goddin, Ibid, hlm, 24-33 dalam Johnny Ibrahim, Ibid, hlm. 33.

11 Oscar Lafontaine, Rancangan Globalisasi (Jawaban Kaum Sosial Demokrat), dalam Ade Ma'ruf dan Anas Syahrul Alimi (editor), Shaping Globalization Jawaban Kaum Sosial Demokrat Atas Neoliberalisme, Kumpulan Makalah dalam International Conference 17 und 18 of June 1998, Willy Brandt Haus, Berlin, diterjemahkan oleh Dian Prativi \& Fatchul Mu'in, Jendela, Yogyakarta, 2000, hlm. 11, dalam Johnny Ibrahim, Ibid. upah kerja oleh pemerintah, dan usaha dalam bidang pendidikan. Gagasan tersebut ternyata diterima oleh berbagai negara seperti Inggris, Jerman, dan Amerika Serikat. $^{12}$

\section{Selanjutnya menurut Goddin} mengingatkan nilai-nilai yang harus dijaga dalam menghadapi perilaku pasar bebas "The market has a corrosive effect' on values, debasing what was formerly precious and apart from mundane world, by allowing everything to be exchanged for everything else. In the end we are left with nothing but a'vending machine society' where everythingis available for a price. (Pasar memiliki dampak yang merusak nilai-nilai, merendahkan derajat terhadap apa yang sebelumnya mulia dan telah dianggap sebagai kebiasaan, yaitu jika membiarkan segala sesuatu dapat dipertukarkan dengan segala yang lainnya. Pada akhirnya, akan ditinggalkannya bukan sebagai apa-apa, tetapi hanya sebagai masyarakat yang menjadi mesin penjual, dimana segalanya tersedia untuk sebuah harga). ${ }^{13}$

12 Muchsan, Peradilan Administrasi Negara, Liberty, Yogyakarta, 1981, hlm. 1, dalam Johnny Ibrahim, ibid.

13 Robert E. Goddin, Op.cit, hlm. 31, dalam Johnny Ibrahim, Ibid, hlm 34. 
Tanpa campur tangan pemerintah (dalam konteks negara kesejahteraan), menurut Goddin "Under the law of the market, those who are dependent could and would be mercilessly exploited. Economically, you can drive a very hard bargain indeed and dependent upon you for satifaction of the need. Morally, however you must do not so" (Di bawah aturan pasar, mereka-mereka yang bergantung pada yang lainnya, akan sangat mudah dieksploitasi tanpa belas kasihan sama sekali. Secara ekonomis Anda dapat saja mengusahakan penawaran yang terbaik terhadap siapapun yang membutuhkan dan bergantung pada Anda untuk memenuhi kebutuhan tersebut. Namun secara moral tindakan tersebut tidak dapat dibenarkan). ${ }^{14}$ Dalam hubungan inilah maka pengaturan di luar kebiasaan pasar (extra market provision) dimaksudkan untuk melindungi eksploitasi terhadap mereka-mereka yang memiliki ketergantungan tersebut, sehingga ketergantungan (dependency) itu tidak dapat dimanfaatkan oleh pihak yang lebih kuat untuk kepentingan mereka,

14 Robert E. Goddin, ibid, hlm. 35, dalam Johnny Ibrahim, Ibid, hlm 34-35. tetapi untuk melindungi mereka yang lemah (protecting the vulnerable).

Dari sudut pandang lain, Sri Redjeki Hartono berpendapat bahwa asas campur tangan terhadap kegiatan ekonomi merupakan salah satu dari tiga asas penting yang dibutuhkan dalam rangka pembinaan cita hukum dari asasasas hukum nasional ditinjau dari aspek Hukum Dagang dan Ekonomi. Dua asas lain adalah asas keseimbangan dan asas pengawasan publik. ${ }^{15}$

\section{Masih menurut Sri Redjeki} Hartono, kegiatan ekonomi yang terjadi dalam masyarakat membutuhkan campur tangan negara, mengingat tujuan dasar kegiatan ekonomi itu sendiri adalah untuk mencapai keuntungan. Sasaran tersebut mendorong terjadinya berbagai penyimpangan bahkan kecurangan yang dapat merugikan pihak-pihak tertentu, bahkan semua pihak. Oleh karena itu bahwa campur tangan negara terhadap kegiatan ekonomi secara umum dalam rangka hubungan hukum yang terjadi tetap dalam batas-batas keseimbangan kepentingan umum semua pihak. Campur tangan negara dalam hal ini

15 Sri Redjeki Hartono, Kapita Selekta Hukum Ekonomi, Mandar Maju, Bandung, 2000, hlm. 13 
adalah dalam rangka menjaga keseimbangan kepentingan semua pihak dalam masyarakat, melindungi kepentingan produsen dan konsumen, sekaligus melindungi kepentingan negara dan kepentingan umum terhadap kepentingan perusahaan atau pribadi. ${ }^{16}$

Friedmann juga berpendapat bahwa dalam konteks ekonomi campuran (mixed economy), ada empat fungsi negara. Pertama negara sebagai penyedia (provider) dalam kapasitas tersebut dilaksanakan upaya untuk memenuhi standar minimal yang diperlukan masyarakat dalam rangka mengurangi dampak pasar bebas yang dapat merugikan masyarakat. Kedua, fungsi negara sebagai pengatur (regulator) untuk menjamin ketertiban agar tidak muncul kekacauan, seperti halnya pengaturan di bidang investasi agar industri dapat tumbuh dan berkembang. Ketiga, campur tangan langsung dalam perekonomian (entrepreneur) melalui BUMN. Keempat, fungsi negara sebagai pengawas (umpire) yang berkaitan dengan berbagai produk aturan hukum untuk menjaga ketertiban dan keadilan sekaligus bertindak sebagai penegak hukum. ${ }^{17}$

Selanjutnya konsep negara kesejahteraan menurut Bagir Manan adalah negara atau pemerintah tidak semata-mata sebagai penjaga keamanan atau ketertiban masyarakat semata, tetapi memikul tanggung jawab utama untuk mewujudkan keadilan sosial, kesejahteraan umum, dan sebesarbesarnya kemakmuran rakyat. ${ }^{18}$ Sejalan dengan pendapat Bagir Manan, menurut Sjahran Basah, berkaitan dengan negara kesejahteraan tersebut, maka tujuan pemerintah tidak sematamata di bidang pemerintahan saja, melainkan harus melaksanakan kesejahteraan sosial dalam rangka mencapai tujuan negara melalui pembangunan nasional. ${ }^{19}$

Sekarang dengan telah diberlakukannya kesepakatan Masyarakat Ekonomi ASEAN (MEA) di kawasan Asia Tenggara, maka hal ini harus dijadikan peluang bagi Indonesia

17 W. Friedmann, The State And The Rule of Law In A Mixed Economy, Stevens \& Sons, London, 1971, hlm. 3,

18 Bagir Manan, Politik Perundang-undangan Dalam Rangka Mengantisipasi Liberalisasi Perekonomian, Fakultas Hukum UNILA, Lampung, 1996, hlm. 16.

19 Sjahran Basah, Eksistensi Dan Tolok Ukur Badan Peradilan Administrasi Di Indonesia, Alumni, Bandung, 1986, hlm. 3. 
untuk unjuk gigi di kancah ASEAN, mengingat Indonesia adalah negara yang kaya dengan sumber daya alam dan sumber daya manusia yang kreatif khususnya dalam industri lokal yang begitu banyak tersebar di masyarakat, serta beragamnya kebudayaan bangsa (traditional knowledge). Dengan melimpahnya sumber daya alam dan sumber daya manusia kreatif serta beragamnya kebudayaan bangsa ini menjadi modal besar bagi Indonesia untuk mampu bersaing dan menguasai pasar ASEAN. Tentu saja sumber dayasumber daya tersebut perlu didukung keberadaannya terutama oleh pihak pemerintah dengan memberikan perlindungan hukum, salah satunya melalui penguatan sistem hukum kekayaan intelektual (KI), karena tidak sedikit produk-produk industri kreatif di masyarakat yang masih belum terlindungi dari segi hukum KI nya. Tidak hanya disitu, peran serta masyarakat juga sangat menentukan sekali dalam pelestarian produk-produk kebudayaan tersebut.

Agus Sardjono dalam bukunya "Membumikan HKI di Indonesia" pernah mengajukan pertanyaan "mengapa musik rock, jazz, dan filmfilm Barat mampu menembus kehidupan sehari-hari bangsa ini, bahkan sampai ke kamar-kamar? Kemudian pernahkah bertanya mengapa anak-anak muda di Eropa, Amerika Serikat, atau Jepang tidak mengenal apalagi menggandrungi gamelan, sebagaimana anak-anak muda Indonesia menyukai musik rock, jazz, pop, atau musik progresif dan sejenisnya? Mengapa anak-anak kecil di Indonesia menyukai Donald Bebek, Scooby Doo, Cinderella, Putri Salju, Superman, Spiderman dan tokoh-tokoh khayalan lainnya? Mengapa anak-anak muda Amerika tidak mengenal Gatotkaca, Werkudoro, Jaka Tingkir, dan tokohtokoh tradisional budaya bangsa Indonesia? Anak-anak SD, SMP bahkan sudah akrab dengan teknologi digital atau alat komunikasi cellular, yang kesemuanya itu bukan produk bangsa ini. $^{20}$

Barangkali pertanyaan-pertanyaan di atas bernada pesimistik, skeptis, dan sinikal. Seolah bangsa ini sudah kalah telak dan tidak berdaya menghadapi gempuran "budaya luar". Namun jika jeli dan menyadari potensi yang belum tergali sepenuhnya, maka sesungguhnya

20 Agus Sardjono, Membumikan HKI di Indonesia, CV. Nuansa Aulia, Bandung, 2009, hlm. 306-307. 
bangsa ini masih memiliki daya saing yang tinggi jika harus berhadapan dengan bangsa-bangsa lain di dunia, khususnya di bidang ekonomi. Bangsa ini dikaruniai berkah dari langit berupa kekayaan sumber daya alam dan sumber daya hayati yang melimpah ruah. Bahkan Indonesia dalam konteks sumber daya hayati termasuk ke dalam tujuh belas (17) negara dengan atribut megadiversity. Kekayaan tambang dan mineral yang dimiliki bangsa ini juga termasuk kategori luar biasa melimpah, mulai dari emas, tembaga, minyak, gas alam, batubara dan sebagainya. Alam yang melingkupi bangsa ini juga memiliki keindahan yang tak terbandingkan, yang mampu menarik minat wisatawan untuk datang dan menikmati keindahannya itu. Belum lagi jika dilengkapi dengan keragaman budaya dan tradisi yang berbanding lurus dengan jumlah ethnic group atau kelompok suku bangsa di negeri ini. ${ }^{21}$

Dari sudut pandang budaya dan tradisi, bangsa ini memiliki potensi sumber daya yang tak terhitung banyaknya. Di setiap sudut desa di Bali misalnya bertebaran seniman-seniman tradisional yang ekspresinya menarik

21 Ibid, hlm. 308. $\begin{array}{llr}\text { bangsa-bangsa } & \text { lain } & \text { untuk } \\ \text { mengeksplorasi } & \text { dan } & \text { bahkan }\end{array}$ mengeksploitasinya. Di setiap sudut kota di Daerah Istimewa Yogyakarta, Surakarta, Pekalongan, dan berbagai kota lainnya bertebaran senimanseniman tradisional yang melahirkan desain-desain batik adiluhung, baik yang klasik maupun kontemporer.

Indonesia juga tidak kekurangan orang-orang yang memahami penggunaan tumbuh-tumbuhan dan sumber daya hayati lainnya sebagai obat-obatan. Bahkan Serat Centhini yang klasik itu telah memuat berbagai ramuan obat-obatan tradisional dan cara penggunaannya untuk mengobati penyakit.

Selain itu, Indonesia juga kaya dengan khasanah seni budaya tradisional lainnya, mulai dari karya grafis, ukiran, musik, tari, sastra dan sebagainya. Bahkan untuk mendokumentasikan semua itu diperlukan kerja raksasa untuk menyelesaikannya. Itupun tidak ada jaminan bahwa semua bentuk ekspresi kebudayaan tradisional itu akan terdokumentasikan dengan lengkap seluruhnya. Itulah bangsa Indonesia yang dapat menjadi faktor menentukan dalam memenangkan persaingan 
dengan bangsa-bangsa lain di bidang produk-produk kebudayaan. Dengan demikian, sesungguhnya tidak ada alasan untuk mengatakan bahwa bangsa ini sudah kalah dalam bersaing dengan bangsa lain. Barangkali jika persaingan itu terjadi pada sektor teknologi, maka memang bangsa ini harus mengakui telah tertinggal jauh dengan bangsabangsa dari negara-negara maju. Namun sesungguhnya bangsa ini masih memiliki keunggulan yang lain, yaitu modal anugerah Tuhan yang sudah disebutkan di atas. Dalam bahasa WIPO (World Intelectual Property Organization) modal yang dimiliki bangsa ini dikenal dengan singkatan GRTKF (Genetic Resources, Tradisional Knowledge and Folklore) yang memiliki keunggulan kompetitif dengan milik bangsa lain. ${ }^{22}$

Masih menurut Agus Sardjono, persoalannya adalah bagaimana menggunakan keunggulan kompetitif dari GRTKF itu dalam rangka persaingan antar bangsa, khususnya di bidang ekonomi dan budaya. Barangkali pilihannya hanya tinggal bagaimana bangsa Indonesia mampu menumbuhkan budaya tertib, budaya

22 Ibid, hlm. 308-309. jujur, budaya disiplin, budaya bersih, budaya kerja keras, dan budaya kreatif menjadi keseharian serta mentalitas dalam bersikap tindak, perilaku dan berpikir. Keseluruhan budaya dan mentalitas itu menjadi syarat mutlak dalam mengelola dan memanfaatkan keunggulan kompetitif bangsa ini untuk bersaing dengan bangsa lain. Seluruh potensi bangsa yang ada tinggal menunggu untuk dikelola dengan mengandalkan budaya kreatif, budaya kerja keras, budaya disiplin, dan budaya jujur. Dalam ranah ekonomi, seluruh potensi bangsa jika digarap dengan benar akan menjadi modal utama untuk memajukan negeri dan mensejahterakan rakyat. Dengan kreatifitas, kerja keras, disiplin, dan jujur, maka potensi sumber daya alam, sumber daya hayati, sumber daya manusia, dan warisan budaya bangsa dapat diubah menjadi hasil produksi yang unggul dan dapat bersaing dengan produk berteknologi bangsa lain. Jujur adalah dasar utama menghargai karya orang lain. Kerja keras adalah dasar utama untuk mewujudkan cita-cita. Kreatif adalah dasar utama untuk tak pernah berhenti mencipta dan menghasilkan karya-karya baru yang memiliki nilai tinggi, baik secara kultural maupun ekonomi. 
Selanjutnya kebersihan, terutama

kebersihan hati adalah syarat utama agar Tuhan berkenan menolong bangsa ini dalam meraih cita-cita memajukan negeri mensejahterakan rakyat. ${ }^{23}$

Moralitas sikap mental terutama kejujuran menjadi penting, karena kejujuran memiliki peranan dan kedudukan strategis dalam kehidupan ini. Kedudukan kejujuran adalah kedudukan kaum yang paling agung. Berani jujur mengatakan bahwa itu adalah karya orang lain, sehingga tidak ada lagi pemalsuan atau pembajakan karya orang lain.

Namun, seberapa banyak pun sumber daya alam yang dimiliki suatu bangsa, suatu saat akan habis juga. Artinya, apabila bangsa Indonesia hanya mengandalkan potensi sumber daya alam tanpa didukung oleh sumber daya yang lainnya seperti dengan penggunaan sistem Hak Kekayaan Intelektual, maka keuntungan yang di dapat tidak akan berlangsung lama. Contoh negara-negara yang minim sumber daya alam, seperti Jepang, Singapura bahkan mampu menjadi negara yang maju dan mencapai tingkat perekonomian yang tinggi dengan mengandalkan sistem HKI.

Oleh karena itu dalam menunjang pembangunan nasional, peningkatan sumber daya manusia di tingkat daerah merupakan bagian yang tidak dapat dipisahkan dari pembangunan nasional itu sendiri. Untuk itu, pada tingkat daerah harus diperkenalkan dan digalakkan pandangan dan sikap terhadap produktivitas kerja yang tinggi dan perilaku yang baik di tempat kerja, akan sangat menunjang keberhasilan pembangunan di daerah. Dalam perkembangan terbaru masalah daya saing sangat terkait dengan bagaimana produk itu dihasilkan dan tidak hanya dengan kombinasi aliran material dari barang mentah ke barang jadi, tetapi lebih pada proses produksi sebagai integrasi pengetahuan, yang terfokus pada jumlah dan kualitas pengetahuan yang dimasukkan ke dalam barang dan jasa yang akan dihasilkan. Aspek lain yang cukup penting saat ini yakni terkait dengan aset-aset tak berwujud, termasuk kekayaan intelektual dalam menilai harga (value) suatu perusahaan. Artinya, saat ini telah dimasukkan aspek hak kekayaan intelektual dalam

23 Ibid, hlm. 309-310. 
memperhitungkan harga dari produk yang akan dilepas ke pasaran. ${ }^{24}$

Konsolidasi ke dalam berupa integrasi (keterpaduan) berbagai lembaga ekonomi yang ada di daerah dalam mengoptimalkan manfaat ekonomi dan sosial, tampaknya menjadi syarat yang penting untuk menjemput arus globalisasi. Masalah ekonomi makro (inflasi, pengangguran, dan defisit neraca pembayaran) juga harus menjadi perhatian daerah, karena kondisi ini sangat berhubungan langsung dengan daerah. Untuk itu dengan struktur ekonomi nasional yang terpadu, seimbang dan didukung oleh perilaku pelaku ekonomi yang transparan, maka persoalan makroekonomi ini dapat dieliminasi.

Salah satu ciri globalisasi adalah informasi. Bila suatu daerah mampu menangkap setiap informasi yang lengkap dan kemudian dapat memanfaatkan dengan menganalisis ketahanan ekonomi, maka daerah tersebut akan terhindar dari strategi pertumbuhan yang direkayasa oleh pihak asing. Kemampuan menganalisis informasi yang ada serta memanfaatkan

24 Ahmad Erani Yustika, Perekonomian Indonesia, Bayu Media, Malang, 2005, hlm. 93. semua informasi itu hanya dapat dilakukan oleh pelaku ekonomi yang berkualitas. Oleh karena itu, strategi meningkatkan kualitas pelaku ekonomi nasional dan daerah merupakan syarat yang cukup mendukung untuk dapat bertahan di tengah arus globalisasi ekonomi. Para pelaku ekonomi di tingkat nasional dan daerah harus terpanggil untuk melakukan berbagai program pelatihan guna meningkatkan keterampilan dalam penguasaan teknologi dan manajemen di berbagai bidang dalam menunjang pertumbuhan ekonomi yang seimbang antara ke dalam dan keluar. ${ }^{25}$

Dari berbagai potensi yang dimiliki Indonesia baik itu sumber daya alam maupun sumber daya manusia yang kreatif serta beragamnya kebudayaan bangsa, semuanya itu tidak akan memberikan keuntungan lebih atau bahkan kesejahteraan masyarakat, justru dengan diterapkannya kesepakatan Masyarakat Ekonomi Asean (MEA) ini malah akan menjadi ancaman bagi bangsa Indonesia. Sumber daya alam yang begitu melimpah tadi akan habis, bahkan akan menjadi sumber keuntungan bangsa lain terutama

25 Ibid, hlm. 92-93. 
negara-negara maju yang memiliki teknologi tinggi terutama dalam bidang HKI.

Seperti beberapa contoh kasus di negara berkembang yang lain sebagai berikut :

1. Dalam kasus Paten Ayahuasca (1999), seorang warga negara Amerika Serikat bernama Loren S. Miller memperoleh paten dari USPTO (patent number 5751) atas varietas tanaman Banisteriopsiscaapi pada tanggal 17 juni 1986. Jenis tanaman ini sebelumnya telah digunakan oleh suku-suku bangsa di sekitar Amazon Basin untuk membuat minuman "ayahuasca" atau "yage". Para dukun (shamans) dari suku bangsa ini menggunakan ayahuasca dalam upacara penyembuhan penyakit. Menurut tradisi setempat, ayahuasca merupakan simbol budaya dan religi seperti halnya salib atau eukaristi (perjamuan suci) bagi ummat Kristen. Tentu saja Miller mengajukan klaim paten itu karena ingin memonopoli manfaat ekonomis dari invention mereka atas teknologi yang terkait dengan ayahuasca tersebut.

2. Dalam kasus Paten Pohon Neem (1996), sebuah perusahaan Amerika (W.R. Grace) memperoleh paten berkaitan dengan biji Neem (Paten dari EPO, No.436257B1). Pohon ini telah digunakan oleh orang-orang India di Pedesaan untuk berbagai keperluan. Klaim monopoli pemanfaatan zat azadirachtin yang terdapat di dalam biji pohon Neem sangat potensial untuk mendatangkan keuntungan ekonomis. Itu sebabnya Grace mengajukan klaim paten atas penemuan mereka dalam memanfaatkan biji pohon Neem. Vandana Shiva melihat monopoli paten itu sebagai suatu tindakan yang tidak fair mengingat pohon Neem telah banyak digunakan oleh masyarakat India. Vandana Shiva kemudian mengajukan gugatan pembatalan paten tersebut ketika Grace memperoleh paten atas extract of neem (azadirachtin).

3. Dalam beberapa media massa yang terbit di Indonesia juga pernah diberitakan adanya 
beberapa paten (utility patent maupun design patent) di luar negeri, atas "teknologi tempe", desain patung Bali, desain batik dan sebagainya, yang pada dasarnya merupakan upaya menggali potensi ekonomis dari penggunaan GRTKF Indonesia oleh pihak-pihak di luar Indonesia.

Menurut Agus Sardjono, contoh di atas menunjukkan adanya potensi ekonomi dari GRTKF. Dalam konteks Indonesia, akankah kita membiarkan potensi ekonomi itu menjadi hanya sekedar potensi bagi masyarakat lokal Indonesia sendiri, ataukah kita akan menggali potensi itu, dan kemudian memanfaatkannya untuk meningkatkan kesejahteraan masyarakat lokal Indonesia. ${ }^{26}$

\section{Istilah traditional knowledge} merupakan masalah hukum baru yang berkembang baik di tingkat nasional maupun internasional. Traditional knowledge telah muncul menjadi masalah hukum baru disebabkan belum ada instrumen hukum domestik yang mampu memberikan perlindungan hukum secara optimal terhadap traditional knowledge yang saat ini banyak dimanfaatkan oleh pihak yang tidak bertanggung jawab. Disamping itu di tingkat internasional traditional knowledge ini belum menjadi suatu kesepakatan internasional untuk diberikan perlindungan hukum. Bagi bangsa Indonesia munculnya permasalahan traditional knowledge ini hendaknya mampu direspon secara optimal. Hal ini mengingat nilai potensial yang dimiliki Indonesia dari traditional knowledge. Respon konkret dapat ditujukan dengan seberapa baik peraturan perundang-undangan yang ada di Indonesia ini mampu merespon hal ini. Sikap responsivitas ini akan membawa Indonesia untuk berupaya melindungi kepentingan nasional menuju persaingan global. $^{27}$

Namun masih menurut Agus Sardjono, sekurang-kurangnya terdapat dua kendala utama dalam menyelesaikan persoalan menyangkut penggunaan GRTKF Indonesia dalam kerangka HKI. Kendala pertama merupakan masalah internal masyarakat lokal Indonesia sendiri. Kedua, merupakan faktor eksternal masyarakat

27 Budi Agus Riswandi dan M Syamsudin, Hak Kekayaan Intelektual dan Budaya Hukum, PT. RajaGrafindo Persada, Jakarta, 2005, hlm. 25-26.

${ }^{26}$ Agus Sardjono, Op. Cit, hlm. 102-105. 
yang menyulitkan masayarakat lokal mengajukan klaim HKI atas penggunaan TKF.

\section{Faktor Internal.}

Masyarakat lokal Indonesia tidak terlampau berorientasi pada aspek ekonomi dalam kaitannya dengan penggunaan TKF. Beberapa daerah di Indonesia menunjukkan bahwa orientasi para traditional healers dalam melakukan pengobatan adalah untuk menolong orang sakit. ${ }^{28}$ Para traditional healers itu tidak berpikir bahwa penggunaan pengetahuan tradisional mereka di bidang obat-obatan dapat mendatangkan keuntungan ekonomis. Tindakan menolong orang sakit bagi para traditional healers adalah merupakan salah satu bentuk kebajikan yang imbalannya adalah kebahagiaan bathiniyah. Oleh sebab itu, pada umumnya para traditional healers tidak pernah meminta bayaran atas jasa pengobatan yang diberikan. Kalaupun ada imbalan, biasanya lebih bersifat simbolis. Para traditional healers pun tidak berminat untuk memonopoli pengetahuan mereka di bidang obat-

28 Agus Sardjono, Pengetahuan Tradisional : Studi mengenai Perlindungan Hak Kekayaan Intelektual Atas Obat-obatan, Program Pascasarjana Fakultas Hukum Universitas Indonesia, Jakarta, 2004, hlm. 112. obatan. Mereka bersifat terbuka ketika datang peneliti-peneliti dari luar menanyakan perihal teknologi pengobatan yang mereka ketahui. Ukuran kebahagiaan bagi masyarakat lokal, termasuk traditional healers bukan pada banyaknya harta benda (property) atau pada aspek material melalui monopoli pengetahuan mereka, melainkan lebih bersifat spiritual. ${ }^{29}$

2. Faktor eksternal.

Kurang responsnya masyarakat lokal terhadap sistem HKI, merupakan faktor lainnya yang menganggap bahwa HKI masih asing bagi mereka. Rezim HKI bersifat individualistik, sementara itu masyarakat lokal bercirikan komunalistik. Rezim HKI berorientasi pada aspek material, khususnya keuntungan ekonomis dari pemanfaatannya. HKI adalah kekayaan (property) yang bernilai komersial. Sementara itu, masyarakat memandang pengetahuan tradisional bukan sebagai property yang mempunyai nilai komersial, melainkan lebih sebagai cultural heritage yang terkadang di dalamnya mengandung nilai magis atau sakral (spiritual). ${ }^{30}$

\footnotetext{
29 Agus Sardjono, Op. Cit, hlm. 107-108.

30 Ibid, hlm. 110-111.
} 
Hak kekayaan intelektual (HKI) sendiri merupakan suatu hal yang baru dalam sistem hukum di Indonesia. Dalam kehidupan masyarakat, pengakuan terhadap karya intelektual sudah ada, tetapi hanya berupa pengakuan secara moral dan etika. Masyarakat Indonesia pada dasarnya merupakan suatu komunitas yang komunal dengan tingkat kebersamaan yang tinggi, sehingga hak-hak individu meskipun ada masih kalah oleh kepentingan bersama. Hak-hak individu tetap dihormati, tetapi pengaturannya sebatas pada aturan dan norma yang tidak tertulis. ${ }^{31}$

Sebagaimana diketahui, bahwa pada tahun 1994 akhirnya Indonesia ikut menandatangani persetujuan pembentukan organisasi perdagangan dunia (WTO) dan meratifikasinya melalui Undang-undang Nomor 7 tahun 1994.

Pasca ratifikasi WTO/TRIPs Agreement, sistem perlindungan hukum HKI di Indonesia mengalami beberapa perubahan, baik dari aspek paradigma (lokal-nasional menjadi internasionalglobal), maupun substansinya (semakin

31 Much. Nurachmad, Segala tentang HAKI Indonesia, Buku Biru, Jogjakarta, 2012, hlm. 17. terstandarisasi dalam bentuk standar minimum TRIPs Agreement, dikaitkan dengan perdagangan). Perubahan tersebut merupakan pengaruh langsung dari perjanjian internasional yang memiliki relevansi dengan persoalan HKI. $^{32}$

Perubahan Undang-Undang HKI yang disesuaikan dengan TRIPs Agreement tersebut, seyogianya tidak bertentangan dan tidak merugikan kepentingan nasional Indonesia. Hal ini penting mengingat pembangunan hukum HKI sebagai bagian dari hukum nasional seyogianya secara filosofis bertumpu pada Pancasila sebagai dasar negara, secara yuridis berdasarkan Undang-Undang Dasar 1945 dan secara sosiologis bersandar pada tata kehidupan dan budaya masyarakat Indonesia. $^{33}$

\section{PENUTUP.}

Dari pembahasan di atas, akhirnya penulis mencoba membuat beberapa kesimpulan dan saran sebagai berikut :

1. Masyarakat Ekonomi Asean (MEA) adalah sebuah komunitas

\footnotetext{
32 Ibid, hlm. 3.

33 Candra Irawan, Op Cit, hlm. 4
} 
negara-negara di kawasan Asean (Asia Tenggara) yang telah samasama menyepakati kerjasama di bidang ekonomi, sosial, politik, keamanan dan lain-lain.

2. Dalam menghadapi MEA, Indonesia sebagai negara hukum berkesejahteraan, sudah seharusnya mengarahkan kepentingannya ke arah tujuan negara sebagaimana yang tercantum pembukaan UndangUndang Dasar 1945 yakni; Melindungi segenap bangsa Indonesia dan seluruh tumpah darah Indonesia, Untuk memajukan kesejahteraan umum, Mencerdaskan kehidupan bangsa, Melaksanakan ketertiban dunia yang berdasarkan kemerdekaan, perdamaian abadi dan keadilan sosial.

3. Masyarakat Ekonomi Asean (MEA) yang saat ini telah dilaksanakan, harus dijadikan peluang bagi Indonesia untuk unjuk gigi di kancah ASEAN, mengingat Indonesia adalah negara yang kaya dengan sumber daya alam dan sumber daya manusia yang kreatif khususnya dalam industri lokal yang begitu banyak tersebar di masyarakat, serta beragamnya kebudayaan bangsa (traditional knowledge), sehingga perlu didukung terutama oleh pihak pemerintah dengan memberikan perlindungan hukum, salah satunya melalui penguatan sistem hukum hak kekayaan intelektual (HKI), karena tidak sedikit produk-produk industri kreatif di masyarakat yang masih belum terlindungi dari segi hukum HKI nya.

4. Bagi bangsa Indonesia munculnya permasalahan

traditional knowledge ini hendaknya mampu direspon secara optimal. Hal ini mengingat nilai potensial yang dimiliki Indonesia dari traditional knowledge. Respon konkret dapat ditujukan dengan seberapa baik peraturan perundang-undangan yang ada di Indonesia ini mampu merespon hal ini. Sikap responsivitas ini akan membawa Indonesia untuk berupaya melindungi kepentingan nasional menuju persaingan global.

\section{DAFTAR PUSTAKA}

A Briggs, The Welfare State in Historical Perspective, dalam; 
Archives Europeennes de $\begin{array}{llll}\text { Sociologie 2: } & 221 & -58\end{array}$ sebagaimana dikutip dari Donald J. Moon (editor) Responsibility Rights \& Welfare, The Teory of the Welfare State, Westview Press Inc., Boulder, Colorado, 1988.

Agus Sardjono, Membumikan HKI di Indonesia, CV. Nuansa Aulia, Bandung, 2009.

Agus Sardjono, Pengetahuan Tradisional : Studi mengenai Perlindungan Hak Kekayaan Intelektual Atas Obat-obatan, Program Pascasarjana Fakultas Hukum Universitas Indonesia, Jakarta, 2004.

Ahmad Erani Yustika, Perekonomian Indonesia, Bayu Media, Malang, 2005.

Bagir Manan, Politik Perundangundangan Dalam Rangka Mengantisipasi Liberalisasi Perekonomian, Fakultas Hukum UNILA, Lampung, 1996.

Huala Adolf, Hukum Ekonomi Internasional, CV Keni Media, Bandung, Cet. Kelima, 2010.

Johnny brahim, Hukum Persaingan Usaha, Bayumedia Publishing, Malang, Cet. 2, 2007.

Much. Nurachmad, Segala tentang HAKI Indonesia, Buku Biru, Jogjakarta, 2012.

Muchsan, Peradilan Administrasi Negara, Liberty, Yogyakarta, 1981.

Oscar Lafontaine, Rancangan Globalisasi (Jawaban Kaum
Sosial Demokrat), dalam Ade Ma'ruf dan Anas Syahrul Alimi (editor), Shaping Globalization Jawaban Kaum Sosial Demokrat Atas Neoliberalisme, Kumpulan Makalah dalam International Conference 17 und 18 of June 1998, Willy Brandt Haus, Berlin, diterjemahkan oleh Dian Prativi \& Fatchul Mu'in, Jendela, Yogyakarta, 2000.

Robert E. Goddin, Reason for Welfare, Economic, Sociological and Political but Ultimately Moral, dalam: Responsibility Right \& Welfare, The Theory of the Welfare State, Donald J. Moon (editor).

Sjahran Basah, Eksistensi Dan Tolok Ukur Badan Peradilan Administrasi Di Indonesia, Alumni, Bandung, 1986.

Sri Redjeki Hartono, Kapita Selekta Hukum Ekonomi, Mandar Maju, Bandung, 2000.

W. Friedmann, The State And The Rule of Law In A Mixed Economy, Stevens \& Sons, London, 1971. 